\title{
Економіка підприємства
}

УДК 657.421.3:17.022.1

JEL classification: D20, M20

Кривда О.В.

канд. економ. наук, доцент ORCID ID: 0000-0003-4398-6298

Національній технічний університет Украӥні «Київський політехнічний інститут імені Ігоря Сікорського»

\section{ДЖЕРЕЛА ТА ДЕТЕРМІНАНТИ РЕПУТАЦІЙНОГО РИЗИКУ СУЧАСНОГО ПІДПРИЕМСТВА}

\section{SOURCES AND DETERMINANTS OF REPUTATION RISK OF MODERN ENTERPRISE}

Більшість підприємств визнають важливість репутації лише тоді, коли вона втрачена або заплямована. Вони прагнуть зосередити свою енергію на видалення загроз, які вже з'явилися. Це не є управління ризиками, ие є кризове управління. Ефективне управління ризиком репутачї̈ починається з визнання того, щуо такий ризик є розривом між очікуваннями зацікавлених сторін та їх виконанням підприсмством. Метою управління репутаційними ризиками є виявлення потенційних джерел та детермінант ризику репутащіï. B результаті дослідження розкрито сутність таких понять: "репутаційні ризики», «управління репутаційними ризиками» суб'єктів підприємництва. Ретельно проаналізовано ризик репутаиї̈ з трьох категорій: культурний ризик; ризик управління та зовнішній ризик. Виявилося, щзо культурний ризик закладений в організаційну культуру підприємства, отже відноситься до кодексів $і$ норм поведінки, процедур і принципів функціонування, системи иінностей компанії. Ризик управління (управлінський та операчійний) стосується сфери прийняття рішень та виконання завдань усіма працівниками підприємства - від найнижчого до найвищого рівня в організаційній структурі. Поява зовнішнього ризику пов'язана з тим, щзо помилки, зроблені різними організаціями, з якими співпрацює підприємство на ринку, опосередковано обтяжують $i$ само підприємство. Розглянуто основні стратегії управління ризиком. Представлено нову класифікацію ризиків ділової репутації сучасних підприємств. Надано класифікацію джерел та причин репутаційного ризику. Проаналізовано різні рівні реакцій зацікавлених сторін та причини їх виникнення. Окреслено основні методи управління репутаційними ризиками підприємств з акиентом на поширення сучасних методів ведення бізнесу в Україні та пов'язані з цчим потенційні небезпеки втрати репутації сучасними підприємствами.

Ключові слова: репутаційні ризики; джерела репутаційного ризику; види ризиків ділової репутації; управління репутаційними ризиками суб'єктів підприємництва; методи управління репутаційними ризиками.

Most businesses recognize the importance of reputation only when it is lost or tarnished. They seek to focus their energy on eliminating threats that have already emerged. This is not risk management, it is crisis management. Effective reputation risk management begins with recognizing that such risk is a gap between the expectations of stakeholders and their performance by the enterprise. The purpose of reputation risk management is to identify potential sources and determinants of reputation risk. The research revealed the essence of the following concepts: "reputation risks", "reputation risk management" of business entities. 
Reputation risk has been carefully analysed in three categories: cultural risk; management risk and external risk. It turned out that cultural risk is embedded in the organizational culture of the enterprise, therefore, refers to codes and standards of behaviour, procedures and principles of operation, the system of values of the company. Management risk (management and operational) refers to the decision-making and tasks area of all employees of the enterprise - from the lowest to the highest level in the organizational structure. The appearance of external risk is due to the fact that the mistakes made by various organizations with which the company cooperates in the market, indirectly burden the enterprise itself. The basic strategies of risk management are considered. The new classification of risks of business reputation of modern enterprises is presented. The classification of sources and causes of reputational risk is given. Different levels of stakeholder reactions and causes of their occurrence are analysed. The main methods of managing the reputational risks of enterprises with emphasis on the spread of modern methods of doing business in Ukraine and related potential risks of loss of reputation by modern enterprises are outlined.

Keywords: reputational risks; sources of reputational risk; types of business reputation risks; management of reputational risks of business entities; methods of managing reputational risks.

Вступ. Репутація є дуже цінним, але водночас чутливим і вразливим нематеріальним активом підприємства. Кожне підприємство майже щоденно наражається якщо не на втрату, то підрив своєї репутації, що може призвести до негативних наслідків у вигляді зменшення продажів, втрати клієнтів, падіння цін на акції та відходу інвесторів. Ризик втрати репутації насправді $є$ неодмінним елементом, який супроводжує кожну людську діяльність у суспільстві. Хоча не можна його уникнути, можна і потрібно ним управляти.

Чим є по суті репутаційний ризик? Ризик у класичній теорії, сформульованій Дж. Міллем та H.I. Сеніором, визначається як збиток, завданий здійсненням обраного рішення. Тому можна сказати, що майже кожна свідома людська дія є такою загрозою, вона ризикована, тому що не можна точно визначити та передбачити їі наслідки. Це пов'язано з тим, що ми живемо в мінливому, бурхливому середовищі, і результати нашої діяльності визначаються багатьма важко передбачуваними чинниками.

Це також стосується підприємства, яке не $є$ безособовим творінням. Його існування не залежить від будівель, машин, комп'ютерів, але залежить від людей. Через те, що кожна людина робить помилки, керівники та працівники підприємства також не можуть уникати їх у своїх рішеннях та діях. Дж. Фолі стверджує, що якщо фірма хоче створити міцну репутацію, вона повинна визнати той факт, що неможливо уникнути неправильних кроків. Припускаючи таку можливість, слід бути підготовленим до швидкої реакції у таких випадках [1]: бути чесним - визнати свою помилку; брати на себе відповідальність - не намагатися скидати іï на інших; бути готовим до змін і прийняття втрат; підготувати й послідовно реалізовувати план відновлення.

Таким чином, відправною точкою процесу управління ризиком репутації компанії є його прийняття. C. Depel, директор The Institute of Risk Management, констатує, що природа бізнесу несе в собі ризик, отже невігластво чи неуцтво відносно нього не $є$ занадто розсудливим ставленням 
[2]. Наступним важливим питанням для розуміння сутності репутаційного ризику визначається розрив між очікуваннями зацікавлених сторін і виконання їх підприємством. Проте це, здавалося б, просте визначення приховує багато тонкощів. Це показує, що ризик репутації виявляється, коли організація не відповідає очікуванням конкретної групи зацікавлених сторін. Таким чином, буде достатньо ознайомитися та задовольнити їхні потреби, щоб усунути розрив та зменшити ризик. Тут, однак, з'являються щонайменше дві проблеми. Перш за все, чи можна знати реальні очікування окремих груп зацікавлених сторін? Навіть якщо припустити, що це можливо, може виявитися, що дії, вжиті для їх задоволення (наприклад, встановлені стандарти обслуговування) будуть менш, ніж задовільні або навіть неадекватні. А. Росс стверджує, що репутація компанії погіршується як в результаті помилки, так і через неправильне сприйняття їх дій (компанія мала добрі наміри, але вони були помилково прийняті). Організації можуть бути покарані не тільки через помилку, а й через те, що вони неправильно встановлюють стандарти обслуговування [3].

По-друге, дуже важко відповідати потребам та вимогам усіх груп зацікавлених сторін через конфлікт інтересів між деякими з них. Зацікавлена сторона - це будь-який суб'єкт (особа або група), який має очікування щодо компанії. Репутація є відносною побудовою. Це функція часткової репутації, яка представлена клієнтами, інвесторами, підрядниками, партнерами, працівниками, політиками, місцевими громадами та засобами масової інформації. Кожна з цих груп має різні пріоритети, які виражаються в різних очікуваннях відносно підприємства. Клієнти очікують високу якість продукції та помірні ціни, інвестори - високі, надійні та швидкі прибутки, постачальники - надійної співпраці, працівники - стабільності працевлаштування і привабливих заробітків, місцеві громади - турботи про навколишнє середовище тощо. Наприклад, якщо компанія вирішить здійснити прибуткові, але неекологічні інвестиції, це відповідатиме очікуванням інвесторів, але вона наразиться на незадоволення або гострий протест місцевих спільнот та засобів масової інформації.

Тому управління ризиками репутації, спрямоване на зменшення розриву між очікуваннями зацікавлених сторін та їх виконанням є дуже складним завданням. За словами Р. Эклса, С. Ньюквіста і Р. Шатца, більшість компаній ігнорують репутаційний ризик, перш за все тому, що менеджери не знають, як їх визначати та вимірювати. Хоча вони вважають, що керують репутацією та навіть ризиком репутації, фактично їх дії в цій області зводяться до пом'якшення та усунення негативних наслідків несприятливої події, яка їх вразила. Це не репутаційний ризик-менеджмент, а кризовий менеджмент. Управління ризиком репутації вимагає ідентифікації потенційних джерел та факторів ризику, щоб їх можна було відстежувати та контролювати [4]. Таким чином, хоча неможливо повністю усунути репутаційний ризик та зменшити цей розрив, ймовірність кризи може бути зменшена шляхом контролю факторів та можливих причин ризику. 
Постановка завдання. Метою статті $є$ розвиток теоретичних основ сутності ризиків ділової репутації підприємств та особливостей управління ними. Для досягнення поставленої у статті мети необхідно розв'язати такі завдання: розкрити сутність таких понять як: «репутаційні ризики», «управління репутаційними ризиками суб'єктів підприємництва»; здійснити класифікацію ризику репутації та ризикоутворювальних чинників розвитку ділової репутації; розглянути основні види репутаційних ризиків бізнесструктур та дослідити механізм управління ними; окреслити методи управління репутаційними ризиками підприємств.

Методологія. Методологічною та теоретичною основою дослідження $\epsilon$ системний підхід, методи аналізу та синтезу, дедукції, теоретичних узагальнень, групування. Інформаційною основою виступають наукові роботи вітчизняних і закордонних вчених, публікації у засобах масової інформації, Інтернет-ресурси.

Результати дослідження. Ризик репутації може мати різні джерела та причини, a значить, i різний характер i масштаб. Перш ніж вони проаналізуються та класифікуються, варто ознайомитись із основними стратегіями управління ризиком взагалі, а саме [2]: передача (трансфер) ризику, уникнення ризику, управління ризиком, пом'якшення ризику.

Трансфер ризику полягає у передачі його повністю або частково іншим юридичним особам, якими найчастіше $\epsilon$ страхові фірми. Передача ризику може також здійснюватися за допомогою інших фінансових інструментів, наприклад, сек'юритизації. Передача ризику може застосовуватися до конкретних, ймовірних подій, таких як хвороба, втрата роботи, крадіжка.

Другим рішенням $є$ уникання ризику. Воно дозволяє уникнути ситуацій, що призводять до певних загроз, наслідки яких відомі та чітко визначені. Це стосується проблем та сфер, що підпадають під дію законодавчих положень та системи етичних стандартів. Помилки, що виникають унаслідок порушення прав (наприклад, корупція, зловживання, шахрайство), не можуть бути виправдані чи пробачені.

Управління ризиками передбачає планування, моніторинг та контроль факторів, які $є$ потенційними причинами ризику. Такий підхід стосується сфери реальної діяльності людини, в якій вона може свідомо приймати рішення, а ії результати можна виміряти. У таких випадках ризик не може бути переданий стороннім особам, і його не можна уникнути.

Існують такі джерела ризику, на який людина не має власне жодного впливу. Мова йде про непередбачувану поведінку інших людей та загрози 3 боку природи (наприклад, повені, пожежі, посухи, урагани). Цього типу ризику неможливо уникнути, повністю перенести на третіх осіб або керувати ним. Єдиним рішенням є пом'якшення або редукція наслідків таких випадків.

Що стосується ризику репутації, то можна брати до уваги лише три рішення: уникнення, управління та пом'якшення наслідків. Репутація компанії є надто складною категорією, щоб ризик їі втрати можна було перенести на якого-небудь суб'єкта господарювання. У будь-якому випадку, 
страхові компанії ще не розробили та не запропонували такої послуги. Вибір рішення залежить від природи джерел та факторів ризику.

На основі аналізу причин і загроз репутації в останні роки впродовж останніх років зроблено класифікацію ризику репутації з трьох категорій [7]: культурний ризик: правовий та етичний; ризик управління: управлінський та операційний; зовнішній ризик: реляційний та ризик середовища.

Культурний ризик закладений в організаційну культуру підприємства, отже відноситься до кодексів і норм поведінки, процедур і принципів функціонування, системи цінностей компанії. В його межах вирізняється правовий та етичний ризик. У випадку юридичного ризику принципи та правила поведінки встановлюються зовнішніми установами, такими як уряд, місцеві адміністративні органи та наглядові комісії. Їх недотримання передбачає чітко визначені правові санкції. Що стосується етичного ризику, то правила встановлюються та приймаються добровільно організацією або дискретно вводяться різними формуваннями думок (наприклад, дослідницькими центрами, асоціаціями, фондами, засобами масової інформації). Етичний ризик віддзеркалює невідповідність між тим, що декларує організація, та тим, що вона робить. Оскільки джерела культурного ризику відносно легко ідентифікувати, підприємство може відносно нього застосовувати стратегію уникання.

Ризик управління (управлінський та операційний) стосується сфери прийняття рішень та виконання завдань усіма працівниками підприємства від найнижчого до найвищого рівня в організаційній структурі. Ризик управління, пов'язаний 3 рішеннями, прийнятими на найвищому рівні, відбивається в результатах роботи компанії в цілому (фінансових результатах, частини ринку, задоволенні клієнтів і т.д.). У свою чергу, операційний ризик є наслідком помилок або недбалості керівників нижчого рівня або безпосередніх виконавців. Їх помилки найчастіше призводять до дефектів продукту, помилок у документах, недоліками в обслуговуванні тощо. Джерела управління ризиком можна ідентифікувати та контролювати, тому відповідною стратегією є управління ризиком. Підприємства вводять в дію різні інструменти у вигляді систем раннього попередження або комісій внутрішнього контролю. Однак вони не гарантують, що цього ризику можна уникнути, тим більш що часто його підгрунтям буває не тільки некомпетентність, скільки зухвалість і необгрунтована впертість керівників.

Джерела культурного та управлінського ризику знаходяться всередині організації. Існують також фактори ризику назовні, i тому існує також зовнішній ризик. Перша група чинників пов'язана 3 тим, що компанія співпрацює на ринку 3 різними організаціями: постачальниками, посередниками, партнерами тощо. Помилки, зроблені ними, опосередковано обтяжують компанію, оскільки вона зробила неправильний вибір, можливо, недостатньо перевірила та проаналізувала потенційного партнера. Ці фактори створюють реляційний ризик. Друга група причин зовнішнього ризику знаходиться в природному, демографічному, технологічному та 
конкурентному середовищі підприємства. Ці причини є джерелом ризику середовища. Неможливо передбачити, контролювати або уникнути таких подій, як затримка доставки через транспортну компанію, постачання неякісної сировини, пожежа на складі, комп'ютерний вірус, поява небезпечного конкурента. Сдиним рішенням є зменшення та пом'якшення їхніх наслідків.

Зазначені типи ризику з вказівкою рекомендованої стратегії подолання ризику репутації представлені в таблиці 1.

Вибір стратегії також обумовлений масштабом кризи, що проявляється в глибині та силі реакції зацікавлених сторін. У таблиці 2 представлені можливі рівні реакції зацікавлених сторін разом із відповідними наслідками від них та можливі причини їх виникнення.

Таблиця 1 - Категорії репутаційних ризиків

\begin{tabular}{|c|c|c|c|}
\hline \multicolumn{2}{|c|}{ Категорії ризику } & Джерела та фактори & Приклади \\
\hline \multirow[t]{2}{*}{$\begin{array}{c}\text { Культурний - } \\
\text { стратегія } \\
\text { уникання }\end{array}$} & юридичний & $\begin{array}{lr}\text { Дотримання: } & \text { торговельні } \\
\text { стандарти, } & \text { кодекси } \\
\text { поведінки, } & \text { місцеві } \\
\text { нормативні акти, галузеві } \\
\text { норми }\end{array}$ & $\begin{array}{l}\text { Фінансові шахрайства } \\
\text { Зловживання } \\
\text { Розтрата } \\
\text { Корупція }\end{array}$ \\
\hline & етичний & $\begin{array}{l}\text { Дотримання: } \quad \text { чесність, } \\
\text { відповідальність, повага } \\
\text { до традицій, стабільність }\end{array}$ & $\begin{array}{l}\text { Невиконання обіцянок } \\
\text { Недобросовісна } \\
\text { комерційна практика } \\
\text { Неправдива реклама }\end{array}$ \\
\hline \multirow[t]{2}{*}{$\begin{array}{c}\text { Менеджмент - } \\
\text { стратегія } \\
\text { управління }\end{array}$} & управлінський & $\begin{array}{lr}\text { Очікувані } & \text { результати: } \\
\text { додана } & \text { вартість } \\
\text { прибуток, } & \text { розмір } \\
\text { дивідендів, частка } & \text { ринку, } \\
\text { план ремонту } & \end{array}$ & $\begin{array}{l}\text { Невиконання фінансових } \\
\text { прогнозів } \\
\text { Втрата довіри клієнтів та } \\
\text { інвесторів }\end{array}$ \\
\hline & операційний & $\begin{array}{l}\text { Очікувані результати: } \\
\text { висока якість продукції, } \\
\text { високий рівень сервісу, } \\
\text { здоров'я та безпека, } \\
\text { своєчасна доставка }\end{array}$ & $\begin{array}{l}\text { Пошкоджений } \\
\text { або продукт з дефектом } \\
\text { Несправність обладнання } \\
\text { або нещасний } \\
\text { протягом } \\
\text { надання послуг }\end{array}$ \\
\hline \multirow[t]{2}{*}{$\begin{array}{c}\text { Зовнішній - } \\
\text { стратегія } \\
\text { пом'якшення }\end{array}$} & реляційний & $\begin{array}{l}\text { Помилки та помилки в дії: } \\
\text { постачальників / агентів } \\
\text { посередників } \\
\text { кооператорів } \\
\text { ризик аутсорсингу }\end{array}$ & $\begin{array}{lr}\text { "Забруднення" } & \text { поганою } \\
\text { репутацією партнера } \\
\text { Зниження } \\
\text { задоволеності } \\
\text { послугами } & \text { клівня } \\
\end{array}$ \\
\hline & середовища & $\begin{array}{l}\text { Непередбачені зміни: } \\
\text { тенденції на світовому } \\
\text { ринку, галузеві тенденції, } \\
\text { нові технології, новий } \\
\text { конкурент, стихійні лиха }\end{array}$ & $\begin{array}{l}\text { Загроза подальшого } \\
\text { розвитку компанії } \\
\text { Загроза існуванню } \\
\text { виживанню компанії }\end{array}$ \\
\hline
\end{tabular}

Перший, найнижчий рівень ризику призводить до розчарування зацікавлених сторін, головним чином споживачів, що може виникнути внаслідок незначних випадкових невдач обслуговування (наприклад, 
невелика затримка доставки) або незначні помилки в спілкуванні (наприклад, відсутність повідомлення про затримку товару). У таких випадках компанія зазнає втрати довіри, що не завдає серйозної шкоди репутації, особливо коли відбувається швидка реакція та виправлення помилки. Трапляється, що через відповідні заходи щодо клієнта (вибачення, приваблива компенсація), компанія може отримати більшу задоволеність клієнтів і навіть покращити свою репутацію.

Низький рівень ризику викликає неприємні здивування зацікавлених сторін, викликаних дещо серйозними помилками (наприклад, доставка неправильної кількості замовлених товарів, доручення транспортування недобросовісному перевізникові). Як наслідок, це може вплинути на довіру не лише клієнтів, а й ділових партнерів та громадськості. Ситуація повинна бути налагоджена, але це вимагає більш тривалого часу та залучення більших ресурсів.

Наступний рівень ризику, середній, стосується виникнення серйозних побоювань серед зацікавлених сторін щодо довіри та чесності компанії. Найпоширенішою причиною цього є випуск на ринок продукту 3 дефектом, який вже траплявся $з$ такими відомими компаніями, як J\&J, Toyota, Intel aбо Samsung. Іншим істотним приводом може бути неналежне поводження 3 працівниками, наприклад, відсутність відповідних умов праці, відстрочені періоди оплати праці та подовження робочого часу. Зменшену довіру виявляють вже не тільки покупці, контрагенти та громадськість, а й працівники та інвестори, стурбовані своїми прибутками. Згадані приклади компаній вказують на можливість відновлення репутації, але це вимагає майстерних і дорогих заходів у довгостроковій перспективі.

Четвертий рівень визначається як високий. Він викликає образу зацікавлених сторін, що призводить до дуже серйозної шкоди репутації, яку компанія ніколи не зможе повністю знівелювати. Такі помилки, як: неправильні інвестиції, екологічні катастрофи та смертельні випадки співробітників виявляються дуже серйозними та відчуваються майже всіма зацікавленими сторонами. Їх важко пробачити, тому що вони, як правило, виникають унаслідок серйозної недбалості та багатьох неправильних рішень керівництва.

Дуже високий рівень ризику викликає обурення - дуже сильна та глибока реакція всіх груп зацікавлених сторін, що призводить до повної втрати довіри до компанії. Знищена репутація не може бути відновлена, компанія втрачає своє право на існування на ринку. Такий результат обумовлений незаконними діями, вчиненими компанією, такими як зловживання, фінансові шахрайства, корупція, які доведені й санкціонуються судовими вироками. Вражаючим прикладом тут може бути справа компанії Enron 10. 
Таблиця 2 - Рівні ризику та відповідна реакція зацікавлених сторін

\begin{tabular}{|c|c|c|c|}
\hline Рівень ризику & $\begin{array}{c}\text { Реакція } \\
\text { зацікавлених сторін }\end{array}$ & Наслідки & Можливі причини \\
\hline Дуже низький & $\begin{array}{l}\text { Розчарування } \\
\text { (disappointment) }\end{array}$ & $\begin{array}{l}\text { Зменшена довіра - } \\
\text { можливе швидке } \\
\text { відновлення за низькою } \\
\text { ціною }\end{array}$ & $\begin{array}{l}\text { Дрібні недоліки в } \\
\text { обслуговуванні } \\
\text { Помилки в } \\
\text { комунікації }\end{array}$ \\
\hline Низький & $\begin{array}{l}\text { Несподіванка } \\
\text { (surprise) }\end{array}$ & $\begin{array}{l}\text { Порушена довіра - } \\
\text { можливе більш } \\
\text { довготривале повернення } \\
\text { за підтримки PR }\end{array}$ & $\begin{array}{l}\text { Невиконання умов } \\
\text { договору } \\
\text { Вибір } \\
\text { некомпетентних } \\
\text { партнерів }\end{array}$ \\
\hline Середній & Побоювання (concern) & $\begin{array}{l}\text { Значне зниження довіри } \\
\text { - можна відновити за } \\
\text { більш тривалий час, але } \\
\text { й за великі кошти }\end{array}$ & $\begin{array}{l}\text { Дефект продукту } \\
\text { Неправильне } \\
\text { поводження з } \\
\text { працівниками }\end{array}$ \\
\hline Високий & Образа (disgust) & $\begin{array}{l}\text { Серйозно підірвана } \\
\text { довіра - неможливо } \\
\text { відновлення в повній } \\
\text { мірі }\end{array}$ & $\begin{array}{l}\text { Помилкові рішення } \\
\text { правління } \\
\text { Загроза } \\
\text { навколишньому } \\
\text { середовищу } \\
\text { Службові нещасні } \\
\text { випадки }\end{array}$ \\
\hline Дуже високий & Обурення (outrage) & $\begin{array}{lr}\text { Повністю } & \text { втрачена } \\
\text { довіра } & \\
- & \text { неможливе } \\
\text { відновлення } & \\
\end{array}$ & $\begin{array}{l}\text { Злочинні вчинки, } \\
\text { напр. розтрата } \\
\text { Корупція } \\
\text { Судові вироки }\end{array}$ \\
\hline
\end{tabular}

На завершення варто зазначити, що проблема ризику репутації набуває нового виміру, коли стикається з сучасними засобами спілкування, такими як Інтернет та соціальні мережі. Виявляється, вони створюють стільки можливостей, скільки й загроз. 3 одного боку, підприємства можуть використовувати їх для проведення маркетингової діяльності: спілкування 3 потенційними та нинішніми клієнтами, реклами та реалізації своїх продуктів, створення іміджу, контактів з партнерами тощо. Проте існує друга сторона медалі. Соціальні мережі дозволяють створити не тільки дуже швидкий контакт та обмін думками між клієнтами, які можуть висловити своє задоволення, а частіше невдоволення продуктом або послугами практично відразу, без будь-яких витрат.

Вони також дозволяють організовувати конкретні акції, які можуть призвести до швидкої реакції компанії. Прикладом цього є акція „Bank Transfer Day", ініційована одним з клієнтів Bank of America після того, як банк запровадив плату за користування дебетовою карткою у листопаді 2011 року. Клієнт закликав своїх друзів перераховувати рахунки з великих банків до місцевих кредитних союзів. У результаті, ледве впродовж місяця на цей крок вирішилося 650 тис. осіб, і великі банки втратили понад 4,5 мільярда доларів депозитів. Врешті-решт, Bank of America вирішив зняти оплату. 
В Україні, де спостерігається значне відставання просування нових технологій, сьогодні також присутні та набувають поширення такі методи, як онлайн-торгівля, просування товарів за допомогою соціальних мереж Facebook та Instagram. Як інструмент поширення інформації про бренд ця соціальна мережа сьогодні набуває все більшого значення для багатьох видів бізнесу.

Восени минулого року глобальна аудиторія Instagram перевищила 400 мільйонів користувачів, збільшившись на 100 мільйонів всього за 9 місяців. I їхнє число зростає в геометричній прогресії. Це робить іiі соціальною платформою, яка найшвидше зростає, серед усіх великих соціальних мереж світового рівня. Навіть більше, за даними аналітичної компанії Forrester Research, вона відрізняється ще й найвищим рівнем взаємодії 3 контентом 3 боку користувачів. Одна 3 важливих переваг Instagram - легкість використання. Для того щоб почати, досить встановити додаток на смартфон і витратити хвилину-дві на реєстрацію. Наявність мобільного додатку робить контакт із потенційною аудиторією набагато простішим, адже це взаємодія без посередників у вигляді пошукових систем та інших платформ.

Водночас ризик втрати репутації стає для компанії найбільш вагомим та небезпечним, адже написати негативний відгук також віднімає у клієнта декілька хвилин i не потребує фінансових затрат, але резонанс може викликати неабиякий. Компанії, які просувають свій бізнес за допомогою соціальних мереж, повинні бути особливо прискіпливими до зворотного зв'язку з потенційними та наявними клієнтами, уважніше відноситися до дрібних деталей, надавати чесну інформацію про себе та свою продукцію. Такий вид діяльності потребує ретельного управління репутаційними ризиками.

Управління ризиками втрати чи погіршення ділової репутації на підприємстві може здійснюватись його маркетинговим відділом, підрозділом ризик-менеджменту. Також може бути створений спеціальний відділ управління репутаційними ризиками. Підприємства зі значними фінансовими можливостями можуть залучати зовнішніх консультантів та експертів, використовувати послуги консалтингових компаній, рейтингових агентств. На підприємствах малого та середнього бізнесу обов'язки 3 управління репутаційними ризиками можуть бути покладені на менеджерів вищої чи середньої ланки чи на окремих працівників маркетингового відділу.

Висновки. Отже, досягнення позитивної ділової репутації та утримання iii на відповідному рівні можливе лише за умов використання ефективного механізму управління репутаційними ризиками, що у майбутньому підвищить рівень довіри 3 боку клієнтів та партнерів, забезпечить конкурентні переваги на ринку та сприятливо відіб'ється на ринковій вартості підприємства. Перспективними напрямами подальших досліджень є: розробка методики прогнозування репутаційних ризиків, зокрема, аналіз потенційних збитків, нанесених підприємству внаслідок погіршення ділової репутації; дослідження особливостей страхування 
репутаційних ризиків з обгрунтуванням мотивації для керівників у цьому виді страхових послуг; вивчення структури та перспектив розвитку репутаційного середовища підприємств.

\section{Література:}

1. Honey G., Short A. Guide to Reputation Risk / G. Honey, A. Short // Gower Publishing, England-USA, 2009. - P. 29.

2. Brady A., Honey G. Corporate Reputation. Perspectives of Measuring and Managing a Principal Risk / A. Brady, G. Honey // The Chartered Institute of Management Accountants, London, 2007. - P. 19-23.

3. Ross A. Reputation: Risk of Risks / A. Ross // The Economist Intelligence Unit, 2005.

4. Eccles R.G., Newquist S.C., Schatz R. Reputation and Its Risks / R.G. Eccles, S.C. Newquist, R. Schatz // Harvard Business Review, 2007.

5. Козлова Н. П. Управление репутационными рисками компании / Н. П. Козлова // Известия ПГПУ им. В. Г . Белинского, 2011. - № 24. - С. 284-287.

6. Дзямулич О. С. Сутність репутаційних ризиків підприємств та особливості управління ними // О. С. Дзямулич // Економічні науки. Серія "Економіка та менеджмент": Збірник наукових праць. Луцький національний технічний університет. - Випуск 11 (42). - Луцьк, 2014. - С. 79-89.

7. Honey G. Integrating Reputation Risk within an ERM framework / G. Honey // Chiron consultants. - January 2012 [Електронний pecypc]. - URL: http://www.theirm.org/events/ documents/Gary_honey.pdf

УДК 338.2 (447)

JEL classification: E43; E62; H21

Ремінський М. М.

ORCID ID: 0000-0003-0756-2228

Глущенко Я. I.

канд. економ. наук, дочент ORCID ID: 0000-0003-1454-0369

Національній технічний університет Україні «Київський політехнічний інститут імені Ігоря Сікорського»

\section{ТЕНДЕНЦЇ̈ І ПРОБЛЕМИ РОЗВИТКУ МАЛОГО ТА СЕРЕДНЬОГО БІЗНЕСУ В УКРАЇ̈I}

\section{TRENDS AND PROBLEMS OF DEVELOPMENT OF SMALL AND MIDDLE BUSINESS IN UKRAINE}

Статтю присвячено діагностиці основних тенденцій та характеристиці проблем розвитку малого і середнього бізнесу в Украӥні. Проведено порівняльний аналіз основних показників, щзо визначають стан малого та середнього бізнесу, в Україні та розвинених країнах світу: кількості зареєстрованих підприємницьких осіб, частки малого та середнього бізнесу в економіиі, кількості зайнятих осіб у малому та середньому бізнесі, частки ВВП виробленої представниками малого та середнього бізнесу. Виявлено, щуо за кількісними характеристиками, малий та середній бізнес в Україні не поступається розвиненим країнам світу, тоді, як частка виробленого ним ВВП значно менша середньоєвропейського показника. Проаналізовано динаміку відсоткових ставок 